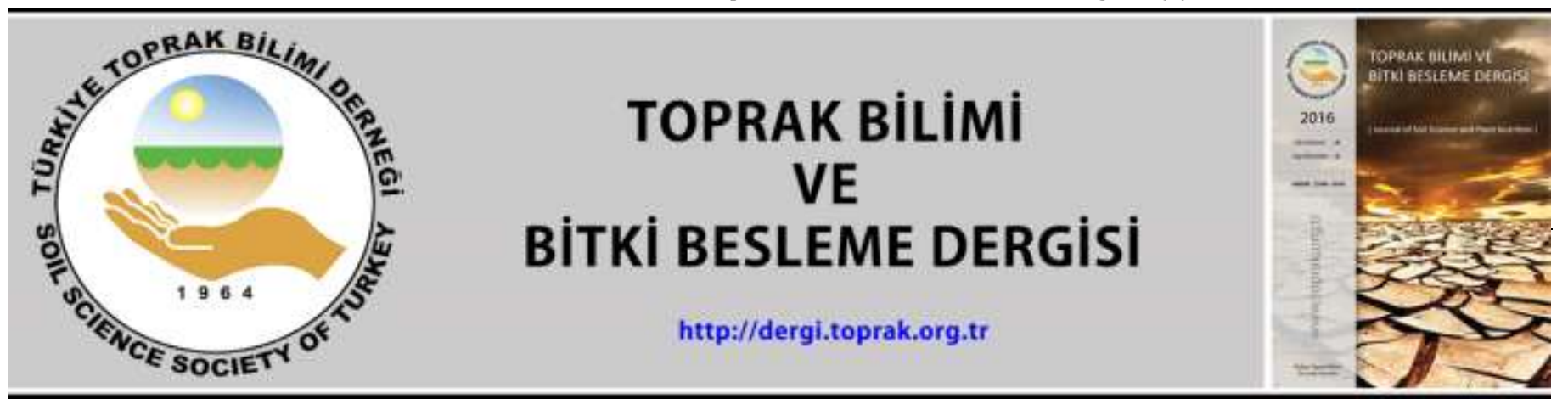

\title{
Organik ve geleneksel çay tarımı uygulamalarının bazı toprak kalite parametreleri ile mikro besin elementi elverişliliği üzerine etkileri
}

\author{
Nutullah Özdemir, Tevhide Önal, Ö.Tebessüm Kop Durmuş *
}

Ondokuz Mayıs Üniversitesi, Ziraat Fakültesi, Toprak Bilimi ve Bitki Besleme Bölümü, Samsun

\begin{abstract}
Özet
$\mathrm{Bu}$ araştırma, Rize ili koşullarında organik ve geleneksel çay tarımı uygulamalarının, bazı toprak kalite parametreleri (tekstür, toprak reaksiyonu, elektriksel iletkenlik, organik madde, katyon değişim kapasitesi) ve mikro besin elementlerinin elverişlilikleri üzerine etkilerini belirlemek üzere yürütülmüștür. Araștırmaya ait toprak örnekleri, Rize ili Çayeli ilçesi Senoz Vadisi'nde belirlenen iki koordinat arasında kalan hat üzerinde bulunan parsellerden $(0-20 \mathrm{~cm})$ alınmıştır. Toprak örnekleri üzerinde yapılan analiz ve değerlendirmeler sonucun da ölçülen toprak kalite parametreleri (tekstür, toprak reaksiyonu, elektriksel iletkenlik, organik madde, katyon değişim kapasitesi) üzerinde, uygulama ve rakım farkının etkisi olduğu saptanmıștır. Daha düşük rakıma sahip geleneksel tarım uygulamalarının yapıldığı yerlerde organik madde miktarı ortalama \%8,75 belirlenirken, daha yüksek rakıma sahip organik tarım uygulamalarının yapıldığı yerlerde organik madde miktarı ortalama \%5,76 olarak belirlenmiștir. Gerek organik ve gerekse geleneksel tarım uygulamaların yapıldığı parsellerde $\mathrm{Fe}, \mathrm{Cu}, \mathrm{Zn}$ ve $\mathrm{Mn}$ içeriklerinin yeterli düzeyde bulundukları tespit edilmiştir. Anahtar Kelimeler: Organik tarım, geleneksel tarım, çay, mikro besin elementi.
\end{abstract}

Effects of organic and traditional tea farming practices on some soil quality parameters and micronutrient availability

\begin{abstract}
This research was carried out to determine the effects of organic and traditional tea farming practices on some soil quality parameters (texture, soil reaction, electrical conductivity, organic matter, cation exchange capacity) and the availability of micronutrients in Rize province conditions. The soil samples of the research were taken from the parcels $(0-20 \mathrm{~cm})$ on the line between the two coordinates determined in the Senoz Valley in Rize province, Çayeli district. As a result of analyzes and evaluations made on soil samples, it was determined that the difference in application and altitude difference on the measured soil quality parameters (texture, soil reaction, electrical conductivity, organic matter, cation exchange capacity). The amount of organic matter is determined at an average of $8.75 \%$ in places where traditional farming practices with lower altitude are performed, whereas the amount of organic matter is determined as $5.76 \%$ in places where higher altitude organic farming practices are performed. It has been determined that $\mathrm{Fe}, \mathrm{Cu}, \mathrm{Zn}$ and $\mathrm{Mn}$ contents are sufficient in the parcels where both organic and traditional agricultural practices are made.
\end{abstract}

Keywords: Organic farming, conventional farming, tea, micro nutrients.

(C) 2020 Türkiye Toprak Bilimi Derneği. Her Hakkı Saklıdır

\section{Giriş}

Çay (Camellia sinensis L.), çaygiller familyasından (Theaceae) nemli iklim koşullarında yetiştirilebilen, çalı şeklinde, çatallanma yeteneği yüksek, devamlı yeşil kalabilen, yaprak ve tomurcukları içecek maddesi üretiminde kullanılan iklim istekleri açısından seçici olan, verim ve kalite yönünden tarımsal uygulamalardan önemli ölçüde etkilenen bir bitkidir (Anonim, 2014; Nath, 2014 ).

Rize yöresi çay topraklarında makro ve mikro besin elementlerinin mevsimsel değişimi ve yeterlilik durumunu araştıran Buçan (2014) ilkbahar mevsiminde pH ve makro element değerlerinin yüksek, mikro element değerlerinin düşük olduğunu, sonbahar mevsiminde ise $\mathrm{pH}$ ve makro element değerlerinin düşük, mikro element değerlerinin genel itibariyle yüksek olduğunu belirlemiştir.

\section{* Sorumlu yazar:}

Tel. $\quad$ : 03623121919

E-posta : tebessüm.kopdurmus@omu.edu.tr
Geliş Tarihi

Kabul Tarihi
e-ISSN

DOI : $10.33409 /$ tbbbd.757336 
Saygın ve ark.(2017) Çataklı Havzası'nın doğu yakasında çay (Camellia sinensis L.) tarımı yapılan toprakların bazı fiziksel ve kimyasal özellikleri ile besin elementi içeriklerini eğim, yükseklik ve fizyoğrafik ünite düzeyinde incelemişlerdir. Elde edilen verilere göre toprakların hâkim bünye sınıfı kumlu tın, reaksiyonları çok kuvvetli ve orta derecede asit olarak belirlenmiştir. Toprakların makro besin elementi içeriklerinden azot, fosfor ve potasyumun, mikro besin elementi içeriklerinden çinko ve manganın yetersiz olduğu, bakır ve demir içeriklerinin ise yeterli düzeyde olduğu saptanmıştır.

Özkutlu ve ark. (2015), Rize merkeze bağlı yerleșim merkezinden uzak köy ve mahallelerde yer alan bazı çay bahçelerinin bitki besin elementi düzeylerini araştırmışlardır. Araştırıcılar 50 farklı bahçeyi esas alarak yaptıkları çalışma sonucunda; bahçelere ait toprakların kumlu tınlı ile killi bünyeye sahip olduğunu, toprak pH' sının 3.49 ile 5.01 arasında değiştiğini, organik madde içeriğinin genelde iyi olduğunu, K, N, Fe, Cu, Zn, Mn ve B bakımından yetersizlikler olduğu tespit etmişlerdir.

Balcı ve ark.(2016), yapmış oldukları bir çalışmada çay topraklarının içermiş oldukları mikro besin elementi durumlarını incelemiş̧lerdir. Araştırıcılar bölgede çay tarımı yapılan alanların dağılımını göz önüne alarak yapmış oldukları değerlendirmeler sonucunda toprakların yarayışlı demir ve mangan içeriklerinin yeterli olduğunu, buna karşılık toprakların bakır ve çinko içeriklerinde yetersizliklerin bulunduğunu belirlemişlerdir. Benzer bir çalışma yürüten Taşkın ve ark. (2015), yapmış oldukları çalışmada toprak ve çay yapraklarındaki makro element düzeylerini irdelemişlerdir. Elde edilen verilere göre toprakların \%70.11'inde kalsiyumun, \%75'inde magnezyumun; çay yapraklarının ise \%81.77'sinde fosforun, \%99.81'inde de potasyumun noksan olduğunu belirlemişlerdir.

Özkutlu ve ark. (2016), Rize çevresindeki bazı çay bahçelerinin bor beslenmesi ve toprak kalite parametreleriyle ilişkisini irdelemişlerdir. Çalışma sonucunda toprakların tamamının tuzsuz, kireç içeriği ve yarayışlı B konsantrasyonları bakımından yetersiz, organik madde içeriklerinin ise ortalama olarak \%4.07 düzeyinde olduğu saptanmıştır. Toprakların B konsantrasyonu ile kireç içeriği ve toprak organik maddesi arasında pozitif, B konsantrasyonu ile toprak pH'sı arasında da negatif düzeyde önemli bir ilişkinin bulunduğu belirlenmiştir. Ayrıca, toprak B konsantrasyonuyla yapraktaki Al içeriği arasında da önemli düzeyde pozitif bir ilişkinin olduğu da saptanmıștır.

Akçanal Ödün (2013), Fırtına Vadisi'nde suni ve doğal gübrelerin oluşturduğu su kirliliğinin aquatik ekosisteme etkisini belirlemek üzere ormanlık alan, gübrelenen çaylık alan ve karışık (çaylık ve ormanlık bir arada) alanları esas alarak yürüttüğü çalışma sonucunda bölgede gübre kullanımının yüzey su kaynaklarının su kalitesini etkilemesi açısından önemli olduğunu görmüştür. Ancak bu farklılıkların zaman ve alan kullanımına göre amonyum azotu hariç diğer faktörlere göre istatistikî açıdan önemli olmadığını tespit etmiştir.

Minh ve ark. (2002), Vietnam'da arazi kullanımındaki değişimin etkilerini araştırmışlardır. Çalışmada tahrip edilmiş olan ormanlık alanların çay tarımına açılması sonucu çay bitkisinin yaşı arttıkça toprağın makro besin elementlerinden potasyum ve fosfor değerlerinin azaldığl, mikro besin elementlerinden demir ve alüminyum oksit değerlerinin arttığı gözlemlenmiştir. Ayrıca toprakların hacim ağırlığı ve sıkışma değeri artarken gözeneklilik, faydalı su ve solucan miktarının azaldığı kaydedilmiştir.

$\mathrm{Bu}$ araştırma Rize İlinde organik ve geleneksel çay tarımı uygulamalarının yapıldığı farklı rakımlara sahip arazilerde, söz konusu uygulamaların bazı toprak kalite parametrelerinin durumu ve mikro besin elementlerinin yeterlilik seviyelerini araştırmak ve uygulama farklılıklarının bu parametreler üzerindeki etkilerini belirlemek üzere yürütülmüştür.

\section{Materyal ve Yöntem}

Araştırmaya ait toprak örnekleri, Karadeniz bölgesi, Rize ili Çayeli ilçesi Senoz Vadisi'ndeki bölgede $41^{\circ} 5^{\prime}$ 24.5508" Kuzey ile 40 43' 39.1260" Doğu koordinatları arasında kalan hat üzerinde bulunan parsellerden alınmıştır. Çalışmada aynı hat üzerinde ve farklı rakımlarda yer alan organik ve geleneksel tarım uygulamalarının yapıldığı çay bahçelerine ait 40 adet yüzey $(0-20 \mathrm{~cm}$ ) toprak örneği kullanılmıştır (Çizelge 1). Toprak tekstürünün belirlenmesinde Bouyoucos hidrometre (Demiralay, 1993); toprak reaksiyonun tespitinde (1:2.5) cam elektrodlu pH-metre aleti (Bayraklı, 1987); elektriksel iletkenliğin belirlenmesinde pH ölçümünün yapıldığı örneklerde cam elektrotlu elektriksel iletkenlik aleti kullanılarak (Bayraklı, 1987); organik madde miktarının belirlenmesinde Walkley-Black yöntemi (Kacar, 1994); tarla kapasitesi (0.33 atm) ve solma noktasındaki (15.0 atm) nem içerikleri basınçlı tabla (Demiralay, 1993), kireç içeriği Scheibler Kalsimetre (Kacar, 1994); katyon değişim kapasitesi (KDK) "Bower” yöntemi (U.S Salinity Lab. Staff, 1954); yarayışlı su içeriği tarla kapasitesindeki ve solma noktasındaki su içeriği değerlerinden yararlanılarak (Demiralay, 1993); topraktaki alınabilir formdaki $\mathrm{Fe}, \mathrm{Cu}, \mathrm{Zn}$ ve $\mathrm{Mn}$ miktarları örnekler $0.05 \mathrm{M}$ DTPA+0.01 $\mathrm{M} \mathrm{CaCl}_{2}+0.01 \mathrm{M}$ TEA $(\mathrm{pH}=7.3)$ ile ekstrakte edildikten sonra açığa çıkan elementler AAS ile okunarak belirlenmiştir (Lindsay ve Norvel, 1969). 


\begin{tabular}{|c|c|c|c|c|c|c|c|}
\hline \multirow{2}{*}{$\begin{array}{l}\text { Örnek } \\
\text { No }\end{array}$} & \multicolumn{3}{|c|}{ Organik Tarım } & \multicolumn{2}{|c|}{ Örnek } & \multicolumn{2}{|c|}{ Geleneksel Tarım } \\
\hline & Rakım & Kullanılan gübre & Alındığı mahalle & No & Rakım & Kullanılan gübre & Alındı̆̆ı mahalle \\
\hline$\overline{1}$ & 400 & Ahır-çay çöpü & Kaptanpaşa & 21 & 10 & NPK(25:5:10) & Sabuncular \\
\hline 2 & 400 & Ahır-çay çöpü & Kaptanpaşa & 22 & 10 & NPK(25:5:10) & Sabuncular \\
\hline 3 & 400 & Ahır-çay çöpü & Kaptanpaşa & 23 & 30 & NPK(25:5:10) & Sabuncular \\
\hline 4 & 400 & Ahır-çay çöpü & Kaptanpaşa & 24 & 30 & NPK(25:5:10) & Sabuncular \\
\hline 5 & 420 & Ahır-çay çöpü & Kaptanpașa & 25 & 50 & NPK(25:5:10) & İncesirt \\
\hline 6 & 420 & Ahır-çay çöpü & Kaptanpaşa & 26 & 50 & NPK(25:5:10) & İncesirt \\
\hline 7 & 440 & Ahır-çay çöpü & Kaptanpaşa & 27 & 80 & NPK(25:5:10) & Madenli \\
\hline 8 & 440 & Ahır-çay çöpü & Kaptanpaşa & 28 & 80 & NPK(25:5:10) & Madenli \\
\hline 9 & 470 & Zenginleşt.çay çöpü & Kaptanpașa & 29 & 100 & NPK(25:5:10) & Madenli \\
\hline 10 & 470 & Zenginleşt.çay çöpü & Kaptanpaşa & 30 & 100 & NPK(25:5:10) & Madenli \\
\hline 11 & 510 & Mikrobiyal & Kaptanpaşa & 31 & 120 & NPK(25:5:10) & Çaybaşı \\
\hline 12 & 510 & Mikrobiyal & Kaptanpaşa & 32 & 120 & $\operatorname{NPK}(25: 5: 10)$ & Çaybaşı \\
\hline 13 & 530 & Mikrobiyal & Kaptanpaşa & 33 & 180 & NPK(25:5:10) & Madenli \\
\hline 14 & 530 & Mikrobiyal & Kaptanpaşa & 34 & 180 & NPK(25:5:10) & Madenli \\
\hline 15 & 550 & Ahir & Ademiç & 35 & 210 & NPK(25:5:10) & Habiboğlu \\
\hline 16 & 550 & Ahir & Ademiç & 36 & 210 & NPK(25:5:10) & Habiboğlu \\
\hline 17 & 700 & Ahır & Ayıșığı & 37 & 220 & NPK(25:5:10) & Habiboğlu \\
\hline 18 & 700 & Ahir & Ayışığı & 38 & 220 & NPK(25:5:10) & Habiboğlu \\
\hline 19 & 720 & Ahir & Arekner & 39 & 240 & NPK(25:5:10) & Habiboğlu \\
\hline 20 & 720 & Ahir & Arekner & 40 & 240 & NPK(25:5:10) & Habiboğlu \\
\hline
\end{tabular}

\section{Bulgular ve Tartışma}

\section{Toprak Özellikleri}

Geleneksel ve organik tarım yapılan çay parsellerinden alınan toprak örneklerinde belirlenen fiziksel ve kimyasal analiz sonuçlarına ait tanımlayıcı istatistikler Çizelge 2'de verilmiştir.

Çizelge 2. Organik çay tarımı yapılan alanlara ait tanımlayıcı istatistikler

\begin{tabular}{|c|c|c|c|c|c|}
\hline Tarım sistemi & Toprak özellikleri & Minimum & Maksimum & Ortalama & Standart sapma \\
\hline \multirow{14}{*}{ Organik tarım } & Kum, $\%$ & 51.78 & 75.99 & 65.822 & 6.0243 \\
\hline & Silt, \% & 11.74 & 26.99 & 20.533 & 5.1101 \\
\hline & Kil, \% & 8.28 & 23.52 & 13.643 & 5.4150 \\
\hline & $\mathrm{pH}(1: 2.5)$ & 4.5 & 7.5 & 5.367 & 0.9620 \\
\hline & $\mathrm{EC},(\mu \mathrm{S} / \mathrm{cm})$ & 57.98 & 665.6 & 319.25 & 168.53 \\
\hline & $\mathrm{OM}, \%$ & 2.19 & 10.65 & 5.763 & 2.5847 \\
\hline & $\mathrm{TK}, \%$ & 13.21 & 24.73 & 17.907 & 3.2803 \\
\hline & SN, $\%$ & 6.08 & 17.97 & 10.04 & 3.184 \\
\hline & $\mathrm{KDK}, \mathrm{me} / 100 \mathrm{~g}$ & 11.186 & 30.878 & 20.363 & 5.512 \\
\hline & $\mathrm{CaCO}_{3}, \%$ & - & - & - & - \\
\hline & $\mathrm{Fe}, \mathrm{ppm}$ & 19.743 & 429.0368 & 165.111 & 105.156 \\
\hline & $\mathrm{Cu}, \mathrm{ppm}$ & 0.3154 & 5.45864 & 1.802385 & 1.794312 \\
\hline & $\mathrm{Zn}, \mathrm{ppm}$ & 1.45504 & 32.2033 & 5.697468 & 9.05882 \\
\hline & $\mathrm{Mn}, \mathrm{ppm}$ & 2.42022 & 332.1567 & 74.792116 & 91.6452 \\
\hline \multirow{14}{*}{ Geleneksel tarım } & Kum, \% & 43.47 & 72.48 & 59.983 & 8.6199 \\
\hline & Silt, \% & 16.56 & 30.39 & 22.563 & 4.9901 \\
\hline & Kil, \% & 10.91 & 26.18 & 18.207 & 4.4480 \\
\hline & $\mathrm{pH}(1: 2.5)$ & 4.12 & 6.72 & 5.041 & 0.7643 \\
\hline & $\mathrm{EC},(\mu \mathrm{S} / \mathrm{cm})$ & 264.8 & 817.6 & 451.66 & 168.741 \\
\hline & $\mathrm{OM}, \%$ & 4.19 & 13.51 & 8.7545 & 3.5995 \\
\hline & $\mathrm{TK}, \%$ & 17.98 & 37.75 & 27.6445 & 5.0930 \\
\hline & $\mathrm{SN}, \%$ & 11.7 & 28.10 & 18.413 & 4.489 \\
\hline & $\mathrm{KDK}, \mathrm{me} / 100 \mathrm{~g}$ & 19.025 & 41.379 & 30.380 & 7.586 \\
\hline & $\mathrm{CaCO}_{3}, \%$ & - & - & - & - \\
\hline & $\mathrm{Fe}, \mathrm{ppm}$ & 35.296 & 378.1152 & 201.38 & 109.87 \\
\hline & $\mathrm{Cu}, \mathrm{ppm}$ & 1.040 & 61.54272 & 12.53 & 18.54 \\
\hline & Zn, ppm & 0.9715 & 33.24852 & 8.96 & 10.49 \\
\hline & Mn, ppm & 12.956 & 56.6889 & 27.44 & 14.57 \\
\hline
\end{tabular}

pH: Reaksiyon; EC: Elektriksel iletkenlik; OM: Organik Madde; TK: Tarla Kapasitesi; SN: Solma Noktası; KDK: Katyon Değișim Kapasitesi; $\mathrm{CaCO}_{3}$;Kalsiyum karbonat; Fe: Demir; Cu: Bakır; Zn: Çinko; Mn: Mangan. 
$\mathrm{Bu}$ verilerin incelenmesinden de anlaşılacağı üzere organik çay tarımı yapılan alanlardaki toprakların ortalama kum içerikleri \%65.82, silt içerikleri \%20.533 ve kil içerikleri ise \%13.643'tür. Toprakların 16 adedi kumlu tın, 2 adedi tınlı kum, 2 adedi kumlu killi tın tekstüre sahiptir. Geleneksel çay tarımı yapılan alanlardaki toprakların ortalama kum içerikleri \%59.983, silt içerikleri \%22.563 ve kil içerikleri ise \%18.21'dir (Çizelge 1). Toprakların bünye dağılımları bakımından 12 adedi kumlu tın, 6 adedi kumlu killi tın ve 2 adedi tın tekstürlüdür. Tekstürel açıdan değerlendirme yapıldığında geleneksel ve organik tarım yapılan parsellerin her ikisinin de tekstürel dağılım açısından benzerlik gösterdiği, aralarında önemli bir farklılığın bulunmadığı tespit edilmiştir. Çay bitkisi yetiştiriciliği açısından kumdan kile değin değișen tekstür aralığına sahip, derin, drenaj sorunu bulunmayan, besin elementlerince zengin toprakların uygun olduğu (Buçan, 2014) dikkate alındığında çalışma alanı topraklarının çay tarımı için uygun yapıda oldukları ifade edilebilir.

Organik çay tarımı yapılan alanlardaki toprakların pH değerleri ortalama 5.36 olup toprakların 10 tanesi kuvvetli asit, 4 tanesi orta asit, 4 tanesi hafif asit, 2 tanesi nötr olarak tespit edilmiștir. Geleneksel çay tarımı yapılan alanlardaki toprakların $\mathrm{pH}$ değerleri ise ortalama 5.04 olup örneklerin 12 tanesi kuvvetli asit, 4 tanesi orta asit, 2 tanesi hafif asit, 2 tanesi nötr olarak tespit edilmiştir. Çay bitkisinin gelişimi açısından optimum pH değeri 4.5-6.0 arasındadır. $\mathrm{pH}^{\prime}$ nın asit ya da alkali yönde değişimi bitki gelişimini olumsuz yönde etkiler (Sarımehmet ve Mahmutoğlu, 1991). Araştırma konusu örnekler bu açıdan değerlendirildiğinde organik tarım uygulamalarının yapıldığı örneklerden nötr reaksiyona sahip olan 2 örneğin alındığı parsel optimum pH aralığının dışında kalmaktadır. Geleneksel tarım yapılan alanlardaki örnekler aynı açıdan irdelendiğinde kuvvetli asit reaksiyona sahip 10 örnekleme parseli pH aralığı açısından bitki gelişimini kısıtlayıcı durumdadır.

Organik çay tarımı yapılan alanlardaki toprakların elektriksel iletkenliği ortalama $319 \mu \mathrm{S} / \mathrm{cm}$ ve geleneksel çay tarımı yapılan alanlardaki toprakların ortalama elektriksel iletkenlik değeri ise $451.66 \mu \mathrm{S} / \mathrm{cm}^{\prime}$ dir (Çizelge 2). Topraklar genel olarak tuzsuz sinıfinda yer almakta olup tuzluluk yönünden herhangi bir sorunun olmadığı ifade edilebilir (Hazelton ve Murphy, 2007).

Organik çay tarımı yapılan alanlardaki toprakların ortalama organik madde içerikleri \%5.76 olup (Çizelge 2) örneklerin 3 tanesi orta, 7 tanesi fazla, 10 tanesi çok fazla sınıfında organik madde içermektedirler. Geleneksel çay tarımı yapılan alanlardaki toprakların ortalama organik madde içerikleri ise \%8.75'tir (Çizelge 2). Örneklerin 8 tanesi fazla, 12 tanesi çok fazla sınıfında organik madde içermektedirler (Ülgen ve Yurtsever, 1995). Gerek organik tarım uygulamalarının ve gerekse geleneksel tarım uygulamalarının yapıldığı parsellere ait örneklerin organik madde yönünden yeterli düzeyde oldukları tespit edilmiștir. Organik ve geleneksel tarım uygulamalarının yapıldığı parsellerin ortalama organik madde içerikleri dikkate alındığında geleneksel tarım yapılan toprakların (\%8.75) organik tarım yapılan topraklara (\%5.76) göre daha yüksek düzeyde organik madde içeriğine sahip oldukları tespit edilmiştir. Çelişkili görünen bu durum muhtemelen organik tarım uygulamalarının geçiş süreci içerisinde (3. yılında) bulunmasına bağlı olarak, ekolojik dengenin yeniden şekillenmesi ile ilişkilidir (Er ve Başalma, 2013).

Organik çay tarımı yapılan alanlardaki toprakların ortalama KDK (me/100g toprakta) değerleri 20.363 ve geleneksel çay tarımı yapılan alanlardaki toprakların KDK (me/100g toprakta) ise 30.38'dir (Çizelge 2). Organik ve geleneksel tarım yapılan toprakların tamamı KDK içerikleri bakımından zengin sınıfına girmektedirler (Hazelton ve Murphy, 2007). Organik ve Geleneksel tarım yapılan parsellere ait örneklerin ortalama KDK içerikleri incelendiğinde organik tarım yapılan parsellerin daha düşük KDK değerlerine sahip olduğu görülmektedir (Çizelge 2). Bu durum muhtemelen toprakların tekstürel ve organik madde içeriklerindeki farklılıktan kaynaklanmış olabilir. Iğdır Ovası yüzey topraklarının fiziksel ve kimyasal özellikleri arasındaki ilişkileri inceleyen Özdemir (1987), kil ve organik madde içeriği ile KDK değerleri arasında pozitif bir ilişkinin bulunduğunu vurgulamıștır.

\section{Mikro Elementler \\ Demir}

Organik çay tarımı yapılan alanlardaki toprakların alınabilir Fe içerikleri 19.74 ppm ile 429.03 ppm arasında değișmekte olup ortalama değer 165.11 ppm'dir (Çizelge 2). Ortalama değerler dikkate alındığında toprakların tümünün yeterlilik açısından 4.5 ppm'in üzerinde ve (Anonymous, 1990) tümünün çok fazla düzeyde demir içerdiği anlaşılmaktadır. Geleneksel çay tarımı yapılan alanlardaki toprakların alınabilir Fe içerikleri ise 35.30 ppm ile 378.15 ppm arasında değişmekte olup ortalama değer 201.38 ppm'dir (Çizelge 4.1). Örnekler elverişli demir yönünden 4.5 ppm'in üzerinde demir içermekte olup (Anonymous, 1990) örneklerin geneli çok fazla düzeyde demir içeriğine sahiptir. 
Ortalama değer dikkate alındığında organik tarım uygulamalarının yapıldığı parsellerin Geleneksel tarım uygulamalarının yapıldığı parsellere göre daha düşük seviyede demir içeriğine sahip oldukları saptanmıştır (Çizelge 2). Bu durum, ilgili parsellerin $\mathrm{pH}$, tekstür ve organik madde içeriğindeki farklılıklardan ve yapılan uygulamalardan kaynaklanmaktadır. Toprakta bulunan bitki besin elementlerinin miktar, çözünürlük ve bitkiye elverişliliği üzerine birçok faktör etki etmektedir. Toprak $\mathrm{pH}^{\prime}$ sının yanında toprağın organik madde içeriği de besin elementi elverişliliğini etkileyen en önemli toprak özelliğidir (De Temmerman ve ark., 2003). Söz konusu faktörlerin etkilerini belirlemek amacıyla yürütülen birçok araştırmada düşük pH değerlerinde $\mathrm{Fe}, \mathrm{Cu}, \mathrm{Zn}, \mathrm{Mn}^{\prime}$ ın değișebilir ve organik bağlı fraksiyonlarının yüksek pH değerlerindekinden daha fazla olduğu belirlenmiştir (Yakupoğlu ve ark., 2010). Organik madde aynı zamanda metalik iyonların değişebilir formda tutulmasında önemli katkılar sağlamaktadır. Organik madde toprak solüsyonundaki kimyasalların kaynağı olup şelatlar ile metallerin bitkilere elverişliliklerini artırmaktadır (Mc Cauley ve ark., 2009).

\section{Bakır}

Organik çay tarımı yapılan alanlardaki toprakların alınabilir bakır içerikleri 0.315 ppm ile 5.459 ppm arasında değişmekte olup ortalama değerleri 1.802 ppm'dir (Çizelge 2). Ortalama değerler dikkate alındığında toprakların tümünün 0.2 ppm'in üzerinde bakır içerdiği (Eyüboğlu ve ark., 1998) ve parsellerin tamamında bitkilere yarayışlı bakır içeriğinin yüksek olduğu ifade edilebilir. Geleneksel çay tarımı yapılan alanlardaki toprakların alınabilir bakır içerikleri ise $1.04 \mathrm{ppm}$ ile $61.543 \mathrm{ppm}$ arasında değişmekte olup ortalama değer 12.53 ppm'dir (Çizelge 2). Örnekler elverişli bakır içeriği yönünden 0.2 ppm'in üzerinde bakır içermekte olup (Eyüboğlu ve ark., 1998) geneli ile yeterli seviyenin üzerinde bakır içeriğine sahiptirler. Ortalama değer dikkate alındığında Geleneksel tarım uygulamalarının yapıldığı parseller organik tarım uygulamalarının yapıldığı parsellere göre daha yüksek düzeyde bakır içeriğine sahiptir (Çizelge 2). Bu durum muhtemelen yapılan gübre uygulamalarının yanında toprak pH'sı, organik madde düzeyleri ve tekstürel yapıdaki farklılıklardan kaynaklanmaktadır. Söz konusu faktörlerin etkilerini belirlemek amacıyla yürütülen birçok araştırmada, düşük $\mathrm{pH}$ değerlerinde $\mathrm{Fe}, \mathrm{Cu}, \mathrm{Zn}$ ve $\mathrm{Mn}$ 'ın değișebilir ve organik bağlı fraksiyonlarının yüksek pH değerlerindekinden daha fazla olduğu belirlenmiştir (Kacar, 1984).

\section{Çinko}

Organik çay tarımı yapılan alanlardaki toprakların alınabilir çinko içerikleri 1.455 ppm ile 32.203 ppm arasında değişmekte olup ortalama değer 5.697 ppm'dir (Çizelge 2). Ortalama değerler dikkate alındığında toprakların tümünün 0.7 ppm'in üzerinde çinko içermekte olduğu, (Viets ve Lindsay, 1973) parsellerin tamamının bitkilere yarayışlı çinko yönünden yeterli düzeyde çinko içerdikleri ifade edilebilir. Geleneksel çay tarımı yapılan alanlardaki toprakların alınabilir çinko içerikleri ise $0.971 \mathrm{ppm}$ ile $33.249 \mathrm{ppm}$ arasında değişmekte olup ortalama değer 8.96 ppm'dir (Çizelge 2). Örnekler elverişli çinko yönünden 0.7 ppm'in üzerinde çinko içermekte olup (Viets ve Lindsay, 1973) örneklerin geneli yeterli düzeyde çinko içeriğine sahiptirler.

Ortalama değer dikkate alındığında Geleneksel tarım uygulamalarının yapıldığı parsellerin organik tarım uygulamalarının yapıldığı parsellere göre daha yüksek düzeyde çinko içeriğine sahip oldukları belirlenmiştir (Çizelge 2). Bu durum muhtemelen yapılan gübre uygulamaları ile birlikte toprak $\mathrm{pH}$ 'sı, organik madde düzeyleri ve tekstürel yapıdaki farklılıklardan kaynaklanmaktadır. Söz konusu faktörlerin etkilerini belirlemek amacıyla yürütülen birçok araştırmada, düşük $\mathrm{pH}$ değerlerinde Zn'nun değişebilir ve organik bağlı fraksiyonlarının yüksek pH değerlerindekinden daha fazla olduğu belirlenmiştir (Bayraklı, 1975)

\section{Manganez}

Organik çay tarımı yapılan alanlardaki toprakların alınabilir manganez içerikleri 2.420 ppm ile 332.157 ppm arasında değişmekte olup ortalama değer 74.792 ppm'dir (Çizelge 2). Ortalama değerler dikkate alındığında örneklerin çoğunlukla (bir örnek hariç) 14 ppm'in üzerinde manganez içeriğine sahip olduğu (Follet ve Lindsay, 1970) parsellerin tamamına yakınının bitkilere yarayışlı manganez açısından yeterli düzeyde oldukları ifade edilebilir. Geleneksel çay tarımı yapılan alanlardaki toprakların alınabilir manganez içerikleri ise 12.956 ppm ile 56.689 ppm arasında değişmekte olup ortalama değer 27.44 ppm'dir (Çizelge 2). Örnekler, elverişli manganez açısından yeterli düzeydedirler (Follet ve Lindsay, 1970)

Ortalama değer dikkate alındığında geleneksel tarım uygulamalarının yapıldığı parsellerin organik tarım uygulamalarının yapıldığı parsellere göre daha yüksek düzeyde manganez içeriğine sahip oldukları saptanmıştır (Çizelge 2). Bu durum muhtemelen toprak pH'sl, organik madde düzeyleri ve tekstürel 
yapıdaki farklılıklardan kaynaklanmaktadır. Söz konusu faktörlerin etkilerini belirlemek amacıyla yürütülen birçok araştırmada, istatistiksel açıdan önemli ilişkiler belirlenmiştir (Foy ve Brown, 1963).

\section{Toprak Kalite Parametreleri ve Mikro Element İçerikleri Arasındaki İlişkiler}

Organik tarım yapılan çay parsellerinden alınan toprak örneklerinde belirlenen toprak kalite parametreleri ve mikro element içerikleri arasındaki ilişkiler Çizelge 3'de, geleneksel tarım uygulamalarının yapıldığı parsellere ait tanımlayıcı istatistikler ise Çizelge 4'de verilmiştir.

Çizelge 3. Organik tarım uygulamalarının yapıldığı parsellere ait toprak kalite parametreleri ve mikro element içerikleri arasındaki ilișkiler

\begin{tabular}{|c|c|c|c|c|c|c|c|c|c|c|c|c|c|}
\hline & Kum & Silt & Kil & TK & SN & $\mathrm{Fe}$ & $\mathrm{Cu}$ & $\mathrm{Zn}$ & $\mathrm{Mn}$ & $\overline{\mathrm{pH}}$ & EC & KDK & OM \\
\hline Kum & 1 & $-.537^{*}$ & $-.605^{* *}$ & $-.755^{* *}$ & $-.675^{* *}$ & $-.628^{* *}$ &,- 256 & ,087 & ,269 & $.459^{*}$ & 377 & $\begin{array}{l}-362 \\
\end{array}$ &,- 317 \\
\hline Silt & & 1 & -346 & ,301 & 090 & $.491^{*}$ & 134 & 231 &,- 035 & -111 & -139 & 176 &,- 136 \\
\hline Kil & & & 1 & $.556^{*}$ & $.665^{* *}$ & 231 & 158 & -,315 & -266 & -,406 & -288 & 235 & $.482^{*}$ \\
\hline TK & & & & 1 & $.840^{* *}$ & ,307 & ,329 & 223 & 109, & -195 &,- 302 & $.537^{*}$ & $.699^{* *}$ \\
\hline SN & & & & & 1 & ,434 & ,234 & ,023 &,- 043 &,- 364 &,- 013 & $.713^{* *}$ & $.786^{* *}$ \\
\hline $\mathrm{Fe}$ & & & & & & 1 & 117, & -185 &,- 318 & $-.463^{*}$ & ,035, & ,314 & ,076 \\
\hline $\mathrm{Cu}$ & & & & & & & 1 & $.724^{* *}$ & $.716^{* *}$ & $.517^{*}$ &,- 419 & ,364 & ,003 \\
\hline $\mathrm{Zn}$ & & & & & & & & 1 & $.948^{* *}$ & $.775^{* *}$ &,- 330 & ,221 & ,092 \\
\hline $\mathrm{Mn}$ & & & & & & & & & 1 & $.810^{* *}$ &,- 220 & ,093 & ,087 \\
\hline $\mathrm{pH}$ & & & & & & & & & & 1 & -197 &,- 016 &,- 336 \\
\hline EC & & & & & & & & & & & 1 & ,000 &,- 005 \\
\hline KDK & & & & & & & & & & & & 1 & $.468^{*}$ \\
\hline $\mathrm{OM}$ & & & & & & & & & & & & & 1 \\
\hline
\end{tabular}

(TK: Tarla Kapasitesi, SN: Solma Noktası, Fe: Demir, Cu: Bakır, Zn: Çinko, Mn: Mangan, pH: Reaksiyon, EC: Elektriksel İletkenlik, KDK: Katyon Değişim Kapasitesi, OM: Organik Madde)

$\mathrm{Bu}$ verilerin incelenmesinden görüleceği üzere organik çay tarımı yapılan alanlardaki topraklara ait kalite parametrelerinden $\mathrm{pH}$ değerleri ile mikroelement içerikleri arasındaki ilişki önemli bulunurken, kum, silt, kil, TK, SN, EC, KDK içerikleri arasında istatistiksel anlamda önemli bir ilişki belirlenememiş olup yalnızca Fe içeriği ile kum içeriği arasında negatif bir ilişki belirlenmiştir.

Çizelge 4. Geleneksel tarım uygulamalarının yapıldığı parsellere ait toprak kalite parametreleri ve mikro element içerikleri arasındaki ilişkiler

\begin{tabular}{|c|c|c|c|c|c|c|c|c|c|c|c|c|c|}
\hline & Kum & Silt & Kil & TK & SN & $\mathrm{Fe}$ & $\mathrm{Cu}$ & $\mathrm{Zn}$ & $\mathrm{Mn}$ & $\mathrm{pH}$ & $\mathrm{EC}$ & KDK & $\mathrm{OM}$ \\
\hline Kum & 1 & $-.876^{* *}$ & $-.727^{* *}$ &,- 020 & ,027 & $-.677^{* *}$ & 169 & 217 & $.467^{*}$ & ,339 & ,074 & 139 & $-.616^{* *}$ \\
\hline Silt & & 1 & 393 & -,051 & -,053 & $.735^{* *}$ &,- 241 &,- 373 & $-.701^{* *}$ & $-.580^{* *}$ & -,132 & -272 & $.646^{* *}$ \\
\hline Kil & & & 1 & 421 & 389 & 357 & -164 & -,126 &,- 225 & -147 & 131 & ,254 & $.553^{*}$ \\
\hline TK & & & & 1 & $.926^{* *}$ & 146 & 104 & 071 & -,158 & -311 & 378, & $.561^{*}$ & 048 \\
\hline SN & & & & & 1 & -053 & 186 &,- 202 & -,174 & -279 & 101 & $.715^{* *}$ & 145 \\
\hline $\mathrm{Fe}$ & & & & & & 1 & 338 & 214 & $-.572^{* *}$ & $-.607^{* *}$ & $.506^{*}$ & $-.452^{*}$ & ,428 \\
\hline $\mathrm{Cu}$ & & & & & & & 1 & $.961^{* *}$ & ,384 & 220 & $.638^{* *}$ & -208 & $-.637^{* *}$ \\
\hline $\mathrm{Zn}$ & & & & & & & & 1 & $.536^{*}$ & 343 & $.561^{*}$ & -099 & $-.675^{* *}$ \\
\hline $\mathrm{Mn}$ & & & & & & & & & 1 & $.934^{* *}$ & -,176 & 335 & $-.774^{* *}$ \\
\hline $\mathrm{pH}$ & & & & & & & & & & 1 &,- 291 & ,224 & $-.645^{* *}$ \\
\hline $\mathrm{Ec}$ & & & & & & & & & & & 1 & -,402 & -,031 \\
\hline KDK & & & & & & & & & & & & 1 &,- 182 \\
\hline $\mathrm{OM}$ & & & & & & & & & & & & & 1 \\
\hline
\end{tabular}

(TK: Tarla Kapasitesi, SN: Solma Noktası, Fe: Demir, Cu: Bakır, Zn: Çinko, Mn: Mangan, pH: Reaksiyon, EC: Elektriksel İletkenlik, KDK: Katyon Değişim Kapasitesi, OM: Organik Madde)

Geleneksel tarım uygulamalarının yapıldığı toprakların kalite parametrelerinden $\mathrm{pH}$ ve organik madde kapsamları ile mikroelement içerikleri arasındaki ilişki önemli bulunurken; kum, silt, kil, TK, SN, EC, KDK içerikleri arasında istatistiksel anlamda önemli bir ilişki belirlenememiş olup, yalnızca Fe ve Mn içeriği ile 
kum içeriği arasındaki ilişki önemli bulunmuştur. İki uygulamanın etkileri irdelendiğinde geleneksel uygulamaların yapıldığı parsellerin daha uygun parametrik değerlere sahip olduğu anlaşılmaktadır. Bu durum muhtemelen organik tarım uygulamalarının geçiş sürecini tamamlamamış olması ilişkili olabilir (Atalay, 2018). Ray ve Mukhopadhyay (2012), Batı Bengal'de çay yetiştirilen topraklar üzerinde yaptıkları bir araştırmada, konum ile organik ve inorganik uygulamaların toprağın fiziko-kimyasal özelliklerindeki değişimi irdelemişlerdir. Yapılan korelasyon çalışması sonucunda, toprak kalite parametrelerinin toprak reaksiyonundan ve uygulamalardan etkilendiği görülmüştür. Yine toprakların bazı kalite parametreleri ve besin elementi içeriklerinin kum içeriği tarafından olumsuz etkilendiği vurgulanmıştır.

\section{Sonuç}

Yapılan değerlendirme sonucunda organik ve geleneksel tarım uygulamalarının araştırmada incelenmiş olan toprak kalite parametreleri ve mikro element içerikleri üzerine etkilerinin Rize koşullarında rakımdan etkilendiği, genelde yüksek rakımlarda yer alan toprakların daha yüksek organik madde ve kil içeriğine sahip oldukları belirlenmiştir. Gerek organik ve gerekse geleneksel tarım uygulamaların yapıldığı parsellerde $\mathrm{Fe}, \mathrm{Zn}$ ve $\mathrm{Mn}$ içeriklerinin yeterli düzeyde bulunduklarl, $\mathrm{Cu}$ içeriğinin ise yüksek düzeyde bulunduğu tespit edilmiştir. Geleneksel tarım uygulamalarının yapıldığı parsellerin organik tarım uygulamalarının yapıldığı parsellere göre ortalama olarak daha uygun toprak kalite koşullarına sahip oldukları görülmüştür. Bu durum muhtemelen organik uygulamaların geçit aşamasında (3. yılında) bulunması ve adaptasyon süreci ile ilişkili olabilir.

\section{Kaynaklar}

Akçanal Ödün N, 2013. Fırtına Vadisi'nde (Çamlıhemşin-Rize) çay tarımında kullanılan suni ve doğal gübrelerin olușturduğu su kirliliğinin akuatik ekosisteme etkisi. Yüksek Lisans Tezi, Recep Tayyip Erdoğan Üniversitesi Fen Bilimleri Enstitüsü, Rize.

Anonim, 2014. Çay. Vikipedi, http://tr,wikipedia,org/wiki/\%C3\%87ay_\%28bitki\%29. Erişim tarihi: 06.03.2014.

Anonymous, 1990. Micronutrient, Assessment at the Country Level: An International Study, FAO Soil Bulletin by Sillanpaa, Rome.

Atalay T, 2018. Organik ve geleneksel çay tarımı uygulamalarının bazı toprak özellikleri ve erozyona duyarlılık üzerine etkileri. Yüksek Lisans Tezi, Ondokuz Mayıs Üniversitesi Fen Bilimleri Enstitüsü, Samsun.

Balcı M, Taşkın MB, Kaya EC, Soba MR, Özer P, Kabaoğlu A, Turan MA, Taban S, 2016. Doğu Karadeniz Bölgesi'nde çay tarımı yapılan toprakların ve çay bitkisinin demir, bakır, çinko ve mangan durumları. Toprak Su Dergisi, 5(2): 6574.

Bayraklı F, 1975. Bayburt ve Erzincan Ovaları ile Rize Bölgesi topraklarının fosfor durumları üzerine bir araştırma. Atatürk Üniversitesi Ziraat Fakültesi Dergisi. 5(4): 39-52.

Bayraklı F, 1987. Toprak ve bitki analizleri. Ondokuz Mayıs Üniversitesi Ziraat Fakültesi Yayınları, No:38, Samsun, 131135.

Buçan Ö, 2014. Çay topraklarındaki makro ve mikro elementlerin mevsimsel değişimi. Yüksek Lisans Tezi, Recep Tayyip Erdoğan Üniversitesi Fen Bilimleri Enstitüsü, Rize.

De Temmerman L, Vanongeval L, Boon, W and Hoenig M, 2003. Heavy metal content of arable soils in Northern Belgium. Water, Air and Soil Pollution. 148: 61-76.

Demiralay İ, 1993. Toprak fiziksel analizleri. Atatürk Üniversitesi Yayınları, No:143, Erzurum, 90-95.

Er C, Başalma D, 2013. Organik tarımdaki gelişmeler. Nobel Akademik Yayıncllık, No:2, 310s.

Eyüboğlu F, Kurucu N, Talaz S, 1998. Türkiye topraklarının bitkiye yarayıșlı bazı mikro elementler ( $\mathrm{Fe}, \mathrm{Cu}, \mathrm{Zn}, \mathrm{Mn})$ bakımından genel durumu. T.C. Başbakanlık Köy Hizmetleri Genel Müdürlüğü Toprak ve Gübre Araştırma Enstitüsü Müdürlüğü Yayınları, Ankara, 72s.

Follet RF, Lindsay WL, 1970. Profile distribution of $\mathrm{Zn}, \mathrm{Fe}, \mathrm{Mn}$ and $\mathrm{Cu}$ in Colarado soils. Colorado State University, Agricultural Experiment Station, Technical Bulletin, 110 p.

Foy CD, Brown JC, 1963. Toxic factors in acis soils. I. Characterization of Aluminum Toxicity in Cotton. Soil Science Amer. Proc. 27: 403-407.

Hazelton P, Murphy B, 2007. Interpreting soil test results: what to do all the numbers mean? Published by CSIRO Publishing. 4(1): 253-263.

Kacar B, 1984. Bitki besleme uygulama klavuzu. Ankara Üni. Yayınları, No:900, Ankara, 149 s.

Kacar B, 1994, Bitki ve toprağın kimyasal analizleri: iii. toprak analizleri. Ankara Üniversitesi Ziraat Fak. Eğitim Araştırma ve Geliștirme Vakfı Yayınları, No:3, Ankara.

Lindsay WL, Norvell WA, 1969. Development of a DTPA micronutrient soil test. Argon, Abstr, 84.

Mc Cauley A, Jones C, Jacobsen J, 2009. Soil pH and organic matter, Nutrient Management Module 8, Montana State University, USA, Available from http://landresources,montana,edu/NM/Modules/Module8,pdf (accessed 8 October 2012).

Minh DG, Anderson DW, Farrell RE, 2002. Indicators for asessing soil quality after long-term tea cultivation in Northern mountainous Vietnam, 17 th WCSS Symposium Thailand, Proc, Books, 32: 1070, 1-12. 
Nath, TN, 2014. Soil bulk density and its impact on soil texture, organic matter content and available macronutrients of tea cultivated soil in dibrugarh district of assam. International Journal of Development Research, 4(2): 343-346.

Özdemir N, 1987. Iğdır ovası yüzey topraklarının bazı fiziksel ve kimyasal özellikleri ile strüktürel dayanıklılık ve erozyona duyarlılık parametreleri arasındaki ilişkiler. Yüksek Lisans Tezi, Atatürk Üniversitesi Fen Bilimleri Enstitüsü, Erzurum(yayınlanmamış).

Özkutlu F, Akkaya ÖH, Ete Ö, Şahin Ö, Korkmaz K, 2015. Rize İlindeki bazı çay bahçelerinin toprak ve yaprak a nalizi ile besin element düzeylerinin belirlenmesi. Harran Tarım ve Gıda Bilimleri Dergisi. 19(2): 96-105.

Özkutlu F, Akaya ÖM, Ete Ö, Akgün M, 2016. Bazı çay bahçelerinin B (Bor) beslenmesi ve toprak özellikleriyle ilişkilerinin belirlenmesi. Ordu Üni. Bilim Teknoloji Dergisi. 6(1): 125-136.

Ray SK, Mukhopadhyay D, 2012. A study on physicochemical properties of soils under different tea growing Regions of West Bengal (India).International Journal of Agriculture Sciences. 4(8): 325-329.

Sarımehmet M, Mahmutoğlu H, 1991. Çayın gübrelenmesi ile ilgili bazı görüş ve öneriler. Çay-Kur Dergisi. 4: 16.

Saygın F, Gürsoy FE, Demirağ Turan İ, Dengiz 0, 2017. Çataklı çayı havzası doğu yakasında çay tarımı yapılan toprakların fiziksel, kimyasal ve verimlilik özelliklerinin belirlenmesi. Türkiye Tarımsal Araştırmalar Dergisi. 2: 143-154.

Taşkın MB, Balcı M, Soba MR, Kaya EC, Özer P, Tanyel G, Kabaoğlu Ali, Turan MA, Taban S, 2015. Doğu Karadeniz Bölgesinde çay tarımı yapılan toprakların ve çay bitkisinin azot, fosfor, potasyum, kalsiyum, magnezyum ve kükürt durumları. Toprak Su Dergisi. 4(2): 30.

U.S. Salinity Lab, Staff. 1954. Diagnosis and Improvement, of saline and alkali soils, U,S,D,A Agriculture Handbook. No: 60.

Ülgen N, Yurtsever N, 1995. Türkiye gübre ve gübreleme rehberi (4. Baskı). T.C. Başbakanlık Köy Hizmetleri Genel Müdürlüğü, Toprak ve Gübre Araştırma Enstitüsü Müdürlüğü Yayınları, Genel Yayın No: 209, Teknik Yayınlar No: T.66, Ankara.

Viets FG, Lindsay WL, 1973. Testing soil for zinc, copper, manganese and iron. Soil Testing and Analysis. Ed: L.W. Walsh, J. D. Peaton. Soil Sci. Soc. America Inc. Madison. U.S.A.

Yakupoğlu T, Özturk E, Özdemir N, Özkaptan S, 2010. Asit topraklarda düzenleyici uygulamalarının mısır bitkisinde mikro element içeriğine etkileri, Anadolu Tarım Bilim Dergisi. 25(2):100-105. 